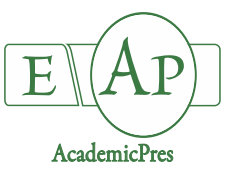

Sanayei S et al. (2021)

Notulae Botanicae Horti Agrobotanici Cluj-Napoca

Volume 49, Issue 2, Article number 11987

DOI: $10.15835 /$ nbha49211987

Research Article

\title{
Amelioration of water deficiency stress in roselle (Hibiscus sabdariffa) by arbuscular mycorrhizal fungi and plant growth-promoting rhizobacteria
}

\author{
Sara SANAYEI ${ }^{1}$, Morteza BARMAKI ${ }^{1 *}$, Ali EBADI ${ }^{1}$, \\ Mousa TORABI-GIGLOU ${ }^{2}$
}

\author{
${ }^{1}$ University of Mohaghegh Ardabili, Faculty of Agriculture, Department of Agronomy and Plant Breeding, Ardabil, Iran; \\ sanayeisa@gmail.com;m_barmaki@uma.ac.ir(*correspondingauthor); ebadi@uma.ac.ir \\ ${ }^{2}$ University of Mohaghegh Ardabili, Faculty of Agriculture, Department of Horticultural Sciences, Ardabil, Iran; mtorabi@uma.ac.ir
}

\begin{abstract}
Belowground interactions between plant roots, arbuscular mycorrhizal fungi (AMFs), and plant growth-promoting rhizobacteria (PGPR) can improve growth and yield under abiotic stress conditions. A pot factorial experiment based on completely randomized design with three replications was conducted to investigate the effects of AMFs (without inoculation as control, inoculation with Funneliformis mosseae and Funneliformis intraradices) and PGPRs (without inoculation as control Pseudomonas fluorescens p-169 inoculation) on roselle (Hibiscus sabdariffa L.) grown under water deficiency stress (WDS) [90\% (I1), 75\% (I2), 50\% (I3), and 25\% (I4) of field capacity as well-watered, mild, moderate, and severe stress, respectively]. The results showed that by applying WDS, the plant growth properties such as root and sepals' dry weight, 1000-seed weight, seed yield, chlorophyll a, b, and total, carotenoids, and leaf water content was significantly reduced. The application of AMFs and PGPR under WDS conditions increased 1000-seed weight, seed yield. In response to WDS osmotic adjustment were provided in Roselle and under stress conditions. The highest seed yield was found under well-watered treatment by inoculation of $F$. mosseae without PGPR and the application of Pseudomonas fluorescens (6.37 and $6.51 \mathrm{~g} / \mathrm{plant}$, respectively). These results suggesting the antagonistic effects of AMFs and PGPR. AMFs inoculation under severe stress increased sepals dry weight compared to the non-inoculation. In conclusion, increased activity of enzymatic antioxidants and higher production of non-enzymatic antioxidant compounds, as well as photosynthetic pigments in symbiotic association with AMFs, can alleviate reactive oxygen species damage resulting in increased growth and yield parameters and improve water stress tolerance.
\end{abstract}

Keywords: antioxidant enzyme activities; limited irrigation; osmotic adjustment; photosynthetic pigments; proline content; root colonization; Roselle; sepals' dry weight

Abbreviations: AMFs, arbuscular mycorrhizal fungi; PGPR, plant growth-promoting rhizobacteria; WDS, water deficiency stress; CAT, catalase activity; POD, peroxides activity; ROS, reactive oxygen species; RWC, relative water content; Chl, chlorophyll content

Received: 02 Jul 2020. Received in revised form: 10 Feb 2021. Accepted: 18 Feb 2021. Published online: 29 Apr 2021.

From Volume 49, Issue 1, 2021, Notulae Botanicae Horti Agrobotanici Cluj-Napoca journal uses article numbers in place of the traditional method of continuous pagination through the volume. The journal will continue to appear quarterly, as before, with four annual numbers. 


\section{Introduction}

Roselle or Mackay tea (Hibiscus sabdariffa L.) belonging to Malvaceae family is an annual industrial and medicinal herb, that widely grown in many countries. This crop probably originated from West Africa or India but is currently grown in many regions of the world, such as parts of Asia, Central America, and Australia (Fallahi et al., 2017). In Iran, roselle is mainly produced in Sistan and Balouchestan province on about 300 ha with a mean dry calyx yield of 700-900 kg/ha (Fallahi et al., 2017). This plant is often used in traditional medicine being rich in phytochemicals like polyphenols especially anthocyanins, polysaccharides, and organic acids thus having enormous prospective in modern therapeutic uses (Riaz and Chopra, 2018). Traditionally, roselle is cultivated for its stem, leaves, calyces, and seeds as all parts have industrial, medicinal and other applications. Roselle fruits (calyx) are containing many essential nutrients such as vitamin A, vitamin C, minerals, polysaccharide, pectin, $\beta$-carotene, anthocyanin, and dietary fiber, also contains alkaloids, ascorbic acid, anisaldehyde, $\beta$-sitosterol, citric-acid, cyanidin-3-rutinoside, delphinidin, galactose, gossypetin, hibiscetin, mucopolysaccharide, protocatechuic acid, quercetin, stearic acid and wax (Ahmad et al., 2010; Fallahi et al., 2017). The plant products (viz., calyx, leaves, oil extracted from seeds) are also reported to be antiseptic, aphrodisiac, astringent, cholagogue, demulcent, digestive, purgative, and resolving. Besides, it is used as a folk remedy in the treatment of abscesses, bilious conditions, cancer, cough, debility, dyspepsia, fever, hangover, heart ailments, hypertension, and neurosis (Da-Costa-Rocha et al., 2014).

Water deficiency stress (WDS) is likely to become more frequent and intense as a result of global climate change, which may severely impact on growth and yield of agricultural, horticultural, and medicinal plants especially in arid and semi-arid parts of the world (Qiao et al., 2020). Hence, due to limited irrigation sources, employing sustainable irrigation methods and systems, including deficit irrigation systems that save water and secure yield, are vital (Amiri et al., 2016). The drought and osmotic stress-induced damage in plants are mainly due to the water shortage or the imbalance of plant water absorption and loss. Therefore, maintaining plant water balance by reducing water loss or increasing root water absorption is an essential way of improving plant tolerance to WDS (Gleason, 2015). In the case of WDS, plants cope with stress by producing and storing osmolytes such as amino acids, sugars, certain minerals, hormones, and proteins. Among organic compositions, amino acid-like proline is one of the most important osmosis regulators that accumulated in all organs of a plant, it has the fastest accumulation in leaves (Sharma et al., 2019).

Water deficiency stress leads to a series of modifications in physiological attributes of a plant such as antioxidant enzymes activity, photosynthesis, photorespiration, and synthesis of amino acid, protein, and carbohydrate (Ahanger et al., 2017). It is generally accepted that stress-induced deregulation of plant metabolism leads to the enhanced production of reactive oxygen species (ROS). To avoid cellular damage due to ROS generation, plants produce some antioxidant enzymes which induce and provide secondary protection against oxidative stress. ROS are generated from abiotic stresses such as salt stress that must be scavenged for the security of essential macromolecules from the destructive effects of ROS and maintenance of normal growth. Moreover, it is the other enzyme that converts two molecules of $\mathrm{H}_{2} \mathrm{O}_{2}$ to water and oxygen. Changes in activities of different antioxidant enzymes under stress conditions were reported in corn (Carrasco-Ríos and Pinto, 2014), stevia (Aghighi Shahverdi et al., 2019), and Brassica oleracea (Soengas et al., 2018). These reports show that the induction of ROS-scavenging enzymes, such as SOD, POD, and CAT, is the most general defence mechanism of WDS or salinity tolerance for detoxifying ROS (Ghahremani et al., 2019).

Under WDS conditions, high fertilizer input does not always guarantee the highest levels of quality and quantity traits of plants (Sbrana et al., 2014). Microorganisms, specifically arbuscular mycorrhizal fungi (AMFs), have already been shown to benefit the host plant through a symbiotic association with the roots (Amiri et al., 2017). The probable mechanisms of increasing tolerance to drought in the plant include increasing hydraulic conductivity of roots, increasing water uptake under low moisture conditions due to the expansion of fungal roots, creating osmotic balance, maintaining Turgor pressure, increasing photosynthetic activity, aggregating carbohydrates and proline and increasing nutrient absorption (Rouphael et al., 2015). The 
mechanisms involved in enhancing the effects of AMFs inoculation have been investigated by several researchers. Improvement of plant nutrient concentration through the inoculation of mycorrhizae when water is limited has been thought to ameliorate water status (Amiri et al., 2017). Additionally, mycorrhizal hyphae have been shown to penetrate the soil pores and absorb water that is normally unavailable for a non-mycorrhizal plant. AMFs inoculation increases the exploratory area for phosphorus and water absorption by expanding the surface area of the plant root (Amiri et al., 2017). These AMFs coexist with the roots of plants and grow inside the cortex cells while increasing roots into the soil, increase the uptake of nutrients, especially phosphorus, which is slightly motile. Usually inoculated plants using water relations and better nutrition compared to others can escape WDS temporally, less damaged, and thus proline and soluble sugar increased less (Al-Arjani et al., 2020). The results of the study have shown that soil fungal growth-promoting bacteria with AMFs increased biomass and mineral uptake even under stressful conditions (Ombódi et al., 2019). According to results and available reports, the use of fluorescent Pseudomonads may be a tool to moderate the effects of drought stress on Hibiscus sabdariffa L. In addition to inducing carbohydrate and protein metabolism related to photosynthesis by Fluorescent Pseudomonads, it has been reported that the soluble sugars of maize inoculated under drought stress are higher than non-inoculated plants (Shoresh et al., 2010).

Plant growth-promoting rhizobacteria (PGPR) of the genus Azotobacter, Azospirillum, and Pseudomonas are among the most important drivers of growth of plants that in addition to nitrogen biostabilization, soil phosphorus solubilizing, and production of significant amounts of growth hormones especially of auxin, gibberellin, and cytokinin affect growth and yield of crops (Gouda et al., 2018). Today, several crops and variety-specific PGPR fertilizers are available in the market and being used by the farmers successfully. Promising results have been reported by the researchers on improvement in growth, yield, pest/disease defence mechanisms, and stress survivability features of the crop plants (Kumar et al., 2020). These bacteria by a variety of ways, including dissolution of low soluble and insoluble compositions, thereby increasing their availability, nitrogen fixation, controlling plant diseases by producing antimicrobial compositions and competition for nutrient uptake, siderophore and plant hormone production such as indole acetic acid (IAA) increase plant tolerance to salinity, drought, and toxicity of the elements (Narula et al., 2000; Awasthi et al., 2011). Soil fluorescent soil pseudomonads especially due to catabolic adaptation, excellent root colonization and production potential of a wide range of enzymes and metabolites that live under various biotic and abiotic stress conditions can be useful, are taken into consideration (Vurukonda et al., 2016). It has been reported that treating plants with plant PGPRs increased proline levels. For example, the treatment of cucumber with a mixture of PGPR strains resulted in an increase in proline content of leaves 3 to 4 times as compared to the control plant (Wang et al., 2012).

Although many studies have been conducted to evaluate WDS tolerance of different medicinal species, so far, no study has been conducted to evaluate the effects of AMFs and PGPR inoculations under WDS on roselle. Therefore, our experiment was performed to determine the effects of AMFs and PGPR inoculation under WDS on morpho-physiological attributes of roselle grown in Iran.

\section{Materials and Methods}

\section{Plant material and experimental design}

A factorial experiment based on randomized complete design (CRD) with three replications of pots was conducted in the greenhouse of the Faculty of Agriculture and Natural Resources, Mohaghegh Ardabili University, Ardabil, Iran in 2016. Experimental factors included WDS [90\% (I1), 75\% (I2), 50\% (I3), and $25 \%$ (I4) of field capacity as well-watered, mild, moderate, and severe stress, respectively], AMFs (noninoculation, F. mosseae, and F. intraradices), and PGPR (control and Pseudomonas fluorescens). The seeds of roselle (Hibiscus sabdariffa L.) were prepared from medicinal herbs Research Institute of Shahid Beheshti University, Iran, two species of AMFs were collected from Soil Biology Laboratory of Tabriz University, Iran 
and we prepared Pseudomonas bacteria from Karaj Soil and Water Research Institute, Iran. The ground used had a 2:1 soil-sand ratio with a loamy clay texture. First, we prepared soil used to disinfect for $1 \mathrm{~h}$ at $100^{\circ} \mathrm{C}$ and then prepared inoculated seedlings with AMFs and PGPR. To inoculate $1 \mathrm{~kg}$ of soil, $50 \mathrm{~g}$ of AMFs will be used (Esmaielpour et al., 2013). After 20 days, the seedlings were transferred to pots. Air temperature ranged from $25{ }^{\circ} \mathrm{C}$ to $27^{\circ} \mathrm{C}$ during the day and $18-21^{\circ} \mathrm{C}$ during the night. Humidity ranged from $60 \%$ to $65 \%$. The greenhouse was lighted using regular and florescence lamps 15-16 h, daily. After the growth of seedlings, we thinned seedlings at several stages and finally, in each pot, we kept 2 plants. WDS treatments were imposed at the flowering stage.

\section{Seed yield components and root characteristics}

At maturity, plants of each pot were harvested. The harvested material such as root volume, root dry weight, sepal dry weight, number of sepals per plant, 1000-seed weight, and seed yield per plant was weighed and counted for these traits. Roots were rinsed free of soil, cut into $1-2 \mathrm{~cm}$ fragments and thoroughly mixed, and subsamples $(1 \mathrm{~g})$ saved for determination of root colonization with AMF. These samples were cleared with $10 \%(\mathrm{w} / \mathrm{v}) \mathrm{KOH}$ and stained with $0.03 \%(\mathrm{v} / \mathrm{v})$ trypan blue in lactoglycerol according to the method of (Phillips and Hayman, 1970), and microscopically examined for colonization by determining percentage root segments containing arbuscules and vesicles using a gridline intercept method (Giovannetti and Mosse, 1980).

\section{Measurement of stomatal conductance}

Rates of stomatal conductance $\left(\mathrm{mol} \mathrm{H}_{2} \mathrm{O} / \mathrm{m}^{2} . \mathrm{sec}\right.$ ) in primary leaves were measured in the growth chamber using a portable photosynthesis measurement system (LI-6400, LI-COR, Inc.). As mentioned above, leaves were irradiated using a metal halide lamp in the growth chamber.

\section{Osmotic potential}

Osmotic potential (MPa) was determined according to (Kusvuran, 2012), $1 \mathrm{~g}$ of fresh leaves from the fourth leaf of the plants was weighed and homogenized with $19 \mathrm{ml}$ distilled water. The homogenized leaf samples were kept at $-20^{\circ} \mathrm{C}$. The homogenized samples were passed from the $0.45 \mu \mathrm{m}$ precision filters. These samples were measured with the freezing point osmometer with Knauer mark and 7400 model instruments (Berlin, Germany). The osmotic potential was calculated according to the Van't Hoff equation.

\section{Relative water content ( $R W C$ )}

$0.2 \mathrm{~g}$ fresh leaf was weighed and placed in $50 \mathrm{ml}$ distilled water for $4 \mathrm{~h}$, and then the turgid leaves were weighed. Then, leaf samples were oven-dried for calculating the dry weight at $70{ }^{\circ} \mathrm{C}$ for $48 \mathrm{~h}$. The RWC was determined by the following equation [1] (Ahmadi et al., 2015).

Equation $[1] \quad \mathrm{RWC}=(\mathrm{FW}-\mathrm{DW}) /(\mathrm{SW}-\mathrm{DW}) \times 100$

whereas, FW: fresh weight, DW: dry weight and SW: saturated weight

\section{Photosynthetic pigments}

Fresh leaf tissue was used for chlorophyll assay. $0.2 \mathrm{~g}$ of leaf tissue was grinded with $80 \%$ acetone gradually to give chlorophyll into acetone solution and finally, the volume of $80 \%$ acetone solution reached 20 $\mathrm{ml}$. The resulting solution was centrifuged at $400 \mathrm{rpm}$ for 10 minutes and then the absorbance of the supernatant was read by spectrophotometer at 470,645, and $663 \mathrm{~nm}$. The amount of chlorophylls and carotenoids were calculated according to the following equations [2-5] (Arnon, 1967).

Equation [2]

Equation [3]

$$
\begin{aligned}
& \text { Chlorophyll a }=(19.3 \times \mathrm{A} 663-0.86 \times \mathrm{A} 645) \mathrm{V} / 100 \mathrm{~W} \\
& \text { Chlorophyll } \mathrm{b}=(19.3 \times \mathrm{A} 645-3.6 \times \mathrm{A} 663) \mathrm{V} / 100 \mathrm{~W}
\end{aligned}
$$


Equation [4]

Equation [5]
Total chlorophyll $=$ chlorophyll a + chlorophyll b

Carotenoids $=100(\mathrm{~A} 470)+3.27(\mathrm{mg} \mathrm{Chl} \mathrm{a})-104(\mathrm{mg} \mathrm{Chl} \mathrm{b}) / 227$

Peroxidase (POD) enzyme assay

Peroxidase enzyme activity was measured by (Kar and Mishra, 1976) method. So that $50 \mu \mathrm{L}$ of the enzyme extract was added to $2.5 \mathrm{ml}$ of reaction solution containing $100 \mathrm{mM}$ of Tris-HCL, $5 \mathrm{mM}$ of oxygenated water and $10 \mathrm{mM}$ pyrogallol in an ice bath and the absorbance changes were read at the wavelength of $425 \mathrm{~nm}$. To compare the activity of the enzyme, a control sample (BLANK) was used. In this sample, $0.05 \mathrm{mM}$ of TrisHCL buffer was used instead of $50 \mu \mathrm{l}$ of the enzyme extract. The enzyme activity was calculated based on the change in uptake in mg of protein per minute.

\section{Catalase (CAT) enzyme assay}

To measure catalase enzyme activity, $2.5 \mathrm{ml}$ of Tris buffer $(50 \mathrm{mM}, \mathrm{pH}=7)$ and $0.3 \mathrm{ml}$ of oxygenated water $(5 \mathrm{mM})$ were prepared, then $60 \mu \mathrm{L}$ of enzyme extract was added in an ice bath and the absorbance was read at the wavelength of $240 \mathrm{~nm}$. To compare the activity of the enzyme, a control sample (BLANK) was also used. In this sample, $0.05 \mathrm{mM}$ of Tris-HCL buffer was used instead of $60 \mu \mathrm{l}$ of enzyme extract. The enzyme activity was calculated based on the change in uptake in mg of protein per minute (Kar and Mishra, 1976).

\section{Measurement of free proline}

For extraction of proline, $0.5 \mathrm{~g}$ of the leaf was grinded using $5 \mathrm{ml}$ of $95 \%$ ethanol in porcelain mortar and the supernatant was removed. The extraction procedure was repeated twice and each time with $5 \mathrm{ml}$ of $70 \%$ ethanol. The solution was centrifuged for 10 minutes at $3500 \mathrm{rpm}$. After separating the liquid phase from the solid phase, the liquid phase was used to extract proline. To determine the concentration of proline, $1 \mathrm{ml}$ of alcoholic extract was diluted with $10 \mathrm{ml}$ distilled water, and $5 \mathrm{ml}$ of ninhydrin reagent was added $(125 \mathrm{mg}$ of ninhydrin $+2 \mathrm{ml}$ of phosphoric acid $6 \mathrm{ml}+3 \mathrm{ml}$ glacial acetic acid). For the preparation of phosphoric acid 6 molars, $40.45 \mathrm{ml}$ of $85 \%$ phosphoric acid (v/v) with a density of $1.71 \mathrm{~kg}$ was added to distilled water and then made to $100 \mathrm{ml}$ volume. Then, $5 \mathrm{ml}$ of glacial acetic acid was added, stirred, and put in boiling water for 45 min. After removing the samples from the boiling water and cooling, add $10 \mathrm{ml}$ of benzene was added and mixed with a mechanical stirrer to allow proline to enter benzene phase. The samples were left for 30 minutes and then using proline we provided calibration curve and the absorbance was measured with a spectrophotometer at $515 \mathrm{~nm}$ (Irigoyen et al., 1992).

\section{Statistical analysis}

Distribution normality of achieved data was done according to the Kolmogorov-Smirnov and ShapiroWilk test. Then the studied traits were statistically analysed by the Statistical Analysis System software (SAS Institute, Cary, NC, USA, and Version 9.2). The differences among means were separated using LSD test (least significant difference) at 0.05 statistical probability level. The Pearson correlation coefficient was used to measure relationships between growth, morph-physiological, and biochemical trains by using SAS software vr.9.2.

\section{Results}

\section{Root colonization, volume, and dry weight}

Results indicated that the effects of WDS, AMFs, and PGPR were significant on root colonization, volume, and dry weight. Also, comparisons of means showed a significant interaction between WDS $\times$ AMF $\times$ PGPR for root volume and root dry weight $(p \leq 0.01)$. WSD induced different changes in root colonization, volume, and dry weight (Table 1). The highest root colonization $(65.8 \%)$ was observed under well-watered $\left(\mathrm{I}_{1}\right)$ 
by $F$. intraradices, and the lowest colonization by all WDS levels under non-inoculation. Also, the coapplication of $F$. mosseae and Pseudomonas fluorescens increased (93.4\%) root colonization compared to the control treatment (data not shown). WSD significantly decreased root volume and dry weight (by $45.1 \%$ and 55.4\% in I4, respectively) while inoculation with AMFs and PGPR increased these traits (Table 1). The highest root volume and dry weight $\left(20.66 \mathrm{ml}\right.$ and $5.47 \mathrm{~g}$, respectively) were observed under normal irrigation $\left(\mathrm{I}_{1}\right)$ by the co-application of $F$. intraradices and Pseudomonas fluorescens and the lowest means of these traits (8.33 $\mathrm{ml}$ and $1.23 \mathrm{~g}$, respectively) in the non-inoculation under severe stress $\left(\mathrm{I}_{4}\right)$ (Figure $1 \mathrm{~A}$ and $\mathrm{B}$ ).

Table 1. Comparisons of means and analysis of variance indicating the effects of WDS, arbuscular mycorrhizal fungi and plant growth promoting rhizobacteria on roselle yield components and physiological properties

\begin{tabular}{|c|c|c|c|c|c|c|c|}
\hline S.O.V & $\begin{array}{c}\text { Root colonization } \\
(\%)\end{array}$ & $\begin{array}{l}\text { Root volume } \\
(\mathrm{ml})\end{array}$ & $\begin{array}{c}\text { Root dry weight } \\
\text { (g) }\end{array}$ & $\begin{array}{l}\text { Sepals dry weight } \\
\text { (g) }\end{array}$ & $\begin{array}{c}\text { Number of sepals per } \\
\text { plant }\end{array}$ & $\begin{array}{c}1000 \text {-seed weight } \\
\text { (g) }\end{array}$ & $\begin{array}{l}\begin{array}{l}\text { Seed yield } \\
(\mathrm{g} / \mathrm{plant})\end{array} \\
\end{array}$ \\
\hline \multicolumn{8}{|c|}{ WDS } \\
\hline II & $43.72 \mathrm{a}$ & $19.33 \mathrm{a}$ & $4.44 \mathrm{a}$ & $2.99 \mathrm{a}$ & $11.22 \mathrm{a}$ & $31.81 \mathrm{a}$ & $5.55 \mathrm{a}$ \\
\hline I2 & $39.86 \mathrm{a}$ & $16.38 \mathrm{~b}$ & $3.72 \mathrm{~b}$ & $2.27 \mathrm{~b}$ & $9.33 \mathrm{~b}$ & $26.57 \mathrm{~b}$ & $4.62 \mathrm{~b}$ \\
\hline $\mathrm{I} 3$ & $34.27 \mathrm{~b}$ & $12.05 \mathrm{c}$ & $2.45 \mathrm{c}$ & $1.17 \mathrm{c}$ & $7.00 \mathrm{c}$ & $23.25 \mathrm{c}$ & $2.85 \mathrm{c}$ \\
\hline I4 & $29.19 \mathrm{c}$ & $10.61 \mathrm{~d}$ & $1.98 \mathrm{~d}$ & $0.70 \mathrm{~d}$ & $5.56 \mathrm{~d}$ & $19.58 \mathrm{~d}$ & $1.54 \mathrm{~d}$ \\
\hline \multicolumn{8}{|c|}{ AMFs } \\
\hline Non-inoculation & $6.1 \mathrm{c}$ & $13.21 \mathrm{~b}$ & $2.53 \mathrm{~b}$ & $1.6 \mathrm{c}$ & $7.58 \mathrm{c}$ & $24.64 \mathrm{~b}$ & $3.12 \mathrm{c}$ \\
\hline F.mosseae & $49.83 \mathrm{~b}$ & $15.17 \mathrm{a}$ & $3.41 \mathrm{a}$ & $1.82 \mathrm{~b}$ & $9.00 \mathrm{a}$ & $25.57 \mathrm{a}$ & $4.33 \mathrm{a}$ \\
\hline F. intraradices & $54.36 \mathrm{a}$ & $15.42 \mathrm{a}$ & $3.51 \mathrm{a}$ & $1.94 \mathrm{a}$ & $8.25 \mathrm{~b}$ & $25.70 \mathrm{a}$ & $3.46 \mathrm{~b}$ \\
\hline \multicolumn{8}{|c|}{ PGPR } \\
\hline Control & $32.81 \mathrm{~b}$ & $14.42 \mathrm{~b}$ & $3.0 \mathrm{~b}$ & $1.85 \mathrm{a}$ & $8.14 \mathrm{~b}$ & $22.95 \mathrm{~b}$ & $3.48 \mathrm{~b}$ \\
\hline $\begin{array}{l}\text { Pseudomonas } \\
\text { fluorescens }\end{array}$ & $40.72 \mathrm{a}$ & $14.78 \mathrm{a}$ & $3.3 \mathrm{a}$ & $1.72 \mathrm{~b}$ & $8.42 \mathrm{a}$ & $27.65 \mathrm{a}$ & $3.80 \mathrm{a}$ \\
\hline \multicolumn{8}{|l|}{ Statistics } \\
\hline WDS $\times$ AMF & * & ** & ** & ** & ** & ** & ** \\
\hline WDS $\times$ PGPR & ns & ns & ${ }^{* *}$ & ${ }^{* *}$ & ns & $* *$ & ** \\
\hline AMF $\times$ PGPR & ${ }_{* *}$ & $* *$ & $* *$ & $* *$ & $* *$ & $* *$ & $* *$ \\
\hline WDS $\times$ AMF $\times$ PGPR & $\mathrm{ns}$ & ** & $*^{* *}$ & ** & * & $* *$ & ** \\
\hline
\end{tabular}

\begin{tabular}{|c|c|c|c|c|c|c|c|c|c|c|}
\hline S.O.V & $\begin{array}{c}\text { Stomatal } \\
\text { conductivity } \\
(\mathrm{mol} / \mathrm{m} 2 . \mathrm{sec} \\
\text { ) }\end{array}$ & $\begin{array}{c}\text { Osmotic } \\
\text { potential } \\
(\mathrm{MPa})\end{array}$ & RWC (\%) & $\begin{array}{l}\text { Chlorophyll } \\
\text { a (mg/g FW) }\end{array}$ & $\begin{array}{c}\text { Chlorophyll } \\
\text { b (mg/g } \\
\text { FW) }\end{array}$ & $\begin{array}{c}\text { Total } \\
\text { chlorophyll } \\
\text { (mg/g FW) }\end{array}$ & $\begin{array}{l}\text { Carotenoids } \\
\text { (mg/g FW) }\end{array}$ & $\begin{array}{c}\text { CAT activity } \\
\text { (U/mg } \\
\text { protein. } \\
\text { min) }\end{array}$ & $\begin{array}{c}\text { POD activity } \\
\text { (U/mg } \\
\text { protein. } \\
\text { min) }\end{array}$ & $\begin{array}{c}\text { Proline } \\
\text { content } \\
(\mu \mathrm{mol} / \mathrm{g} \\
\mathrm{FW})\end{array}$ \\
\hline \multicolumn{11}{|c|}{ WDS } \\
\hline II & $16.87 \mathrm{a}$ & $11.01 \mathrm{~d}$ & $86.49 \mathrm{a}$ & $5.85 \mathrm{a}$ & $2.14 \mathrm{a}$ & $7.99 \mathrm{a}$ & $1.94 \mathrm{a}$ & $5.32 \mathrm{~d}$ & $1.06 \mathrm{~d}$ & $5.73 \mathrm{~d}$ \\
\hline I2 & $13.4 \mathrm{~b}$ & $11.64 \mathrm{c}$ & $77.61 \mathrm{~b}$ & $5.17 \mathrm{~b}$ & $1.7 \mathrm{~b}$ & $6.87 \mathrm{~b}$ & $1.48 \mathrm{~b}$ & $5.96 \mathrm{c}$ & $1.36 \mathrm{c}$ & $6.9 \mathrm{c}$ \\
\hline I3 & $12.17 \mathrm{c}$ & $14.5 \mathrm{~b}$ & $64.52 \mathrm{c}$ & $4.34 \mathrm{c}$ & $1.28 \mathrm{c}$ & $5.61 \mathrm{c}$ & $1.03 \mathrm{c}$ & $7.64 \mathrm{~b}$ & $1.88 \mathrm{~b}$ & $8.07 \mathrm{~b}$ \\
\hline I4 & $11.14 \mathrm{~d}$ & $15.73 \mathrm{a}$ & $58.22 \mathrm{~d}$ & $3.67 \mathrm{~d}$ & $1.04 \mathrm{~d}$ & $4.71 \mathrm{~d}$ & $0.85 \mathrm{~d}$ & $8.92 \mathrm{a}$ & $2.33 a$ & $9.74 \mathrm{a}$ \\
\hline \multicolumn{11}{|c|}{ AMFs } \\
\hline $\begin{array}{l}\text { Non- } \\
\text { inoculation }\end{array}$ & $13.01 \mathrm{c}$ & $13.68 \mathrm{a}$ & $68.19 \mathrm{~b}$ & $4.24 \mathrm{~b}$ & $1.46 \mathrm{c}$ & $5.7 \mathrm{~b}$ & $1.15 \mathrm{c}$ & $5.42 \mathrm{c}$ & $1.47 \mathrm{c}$ & $6.71 \mathrm{~b}$ \\
\hline F. mosseae & $13.47 \mathrm{~b}$ & $12.84 \mathrm{~b}$ & $73.2 \mathrm{a}$ & $5.06 \mathrm{a}$ & $1.52 \mathrm{~b}$ & $6.57 \mathrm{a}$ & $1.39 \mathrm{~b}$ & $8.23 \mathrm{a}$ & $1.65 \mathrm{~b}$ & $8.18 \mathrm{a}$ \\
\hline $\begin{array}{l}F \\
\text { intraradices }\end{array}$ & $13.71 \mathrm{a}$ & $13.13 \mathrm{~b}$ & $73.74 \mathrm{a}$ & $4.97 \mathrm{a}$ & $1.63 \mathrm{a}$ & $6.61 \mathrm{a}$ & $1.44 \mathrm{a}$ & $7.23 \mathrm{~b}$ & $1.86 \mathrm{a}$ & 7.95 a \\
\hline \multicolumn{11}{|c|}{ PGPR } \\
\hline Control & $13.03 \mathrm{~b}$ & $13.55 \mathrm{a}$ & $71.18 \mathrm{~b}$ & $4.59 \mathrm{~b}$ & $1.54 \mathrm{a}$ & $6.12 \mathrm{~b}$ & $1.31 \mathrm{~b}$ & $6.61 \mathrm{~b}$ & $1.65 \mathrm{a}$ & $6.88 \mathrm{~b}$ \\
\hline $\begin{array}{l}\text { Pseudomona } \\
\text { sfluorescens }\end{array}$ & $13.76 \mathrm{a}$ & $12.89 \mathrm{~b}$ & $72.24 \mathrm{a}$ & $4.93 \mathrm{a}$ & $1.54 \mathrm{a}$ & $6.46 \mathrm{a}$ & $1.34 \mathrm{a}$ & $7.31 \mathrm{a}$ & $1.67 \mathrm{a}$ & $8.34 \mathrm{a}$ \\
\hline \multicolumn{11}{|l|}{ Statistics } \\
\hline $\begin{array}{l}\text { WDS } \times \\
\text { AMF }\end{array}$ & ** & ns & ns & ** & ** & ** & $* *$ & ** & * & ** \\
\hline $\begin{array}{l}\text { WDS } \times \\
\text { PGPR }\end{array}$ & ns & * & * & ** & $* *$ & $* *$ & $* *$ & ns & $* *$ & ns \\
\hline $\begin{array}{l}\text { AMF } \times \\
\text { PGPR }\end{array}$ & ** & $* *$ & ** & ** & $* *$ & $* *$ & $* *$ & ** & $* *$ & $* *$ \\
\hline $\begin{array}{l}\text { WDS } \times \\
\text { AMF } \times \\
\text { PGPR }\end{array}$ & $* *$ & $* *$ & ** & ** & ** & $* *$ & ** & $* *$ & $* *$ & $* *$ \\
\hline
\end{tabular}

I1, I2, I3, and I4 indicate irrigation levels (WDS treatment) at $90 \%, 75 \%, 50 \%$ and $25 \%$ of field capacity, respectively Means followed by different letters, in the same columns, are significantly different at $p \leq 0.05$ by LSD test. ns, and ${ }^{*},{ }^{* *}$ show no significant differences at 0.05 , and 0.01 level of probability, respectively 

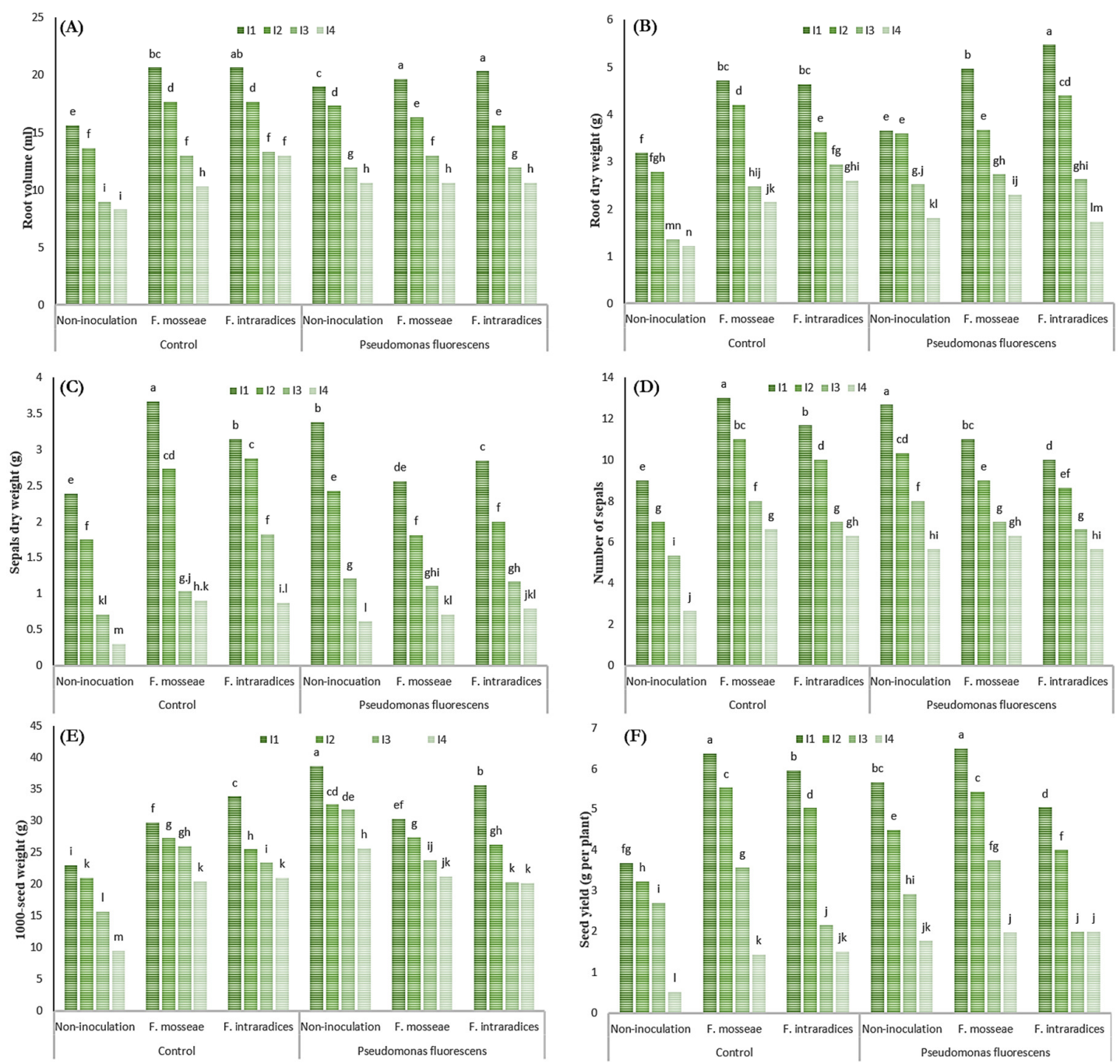

Figure 1. The interaction effects of WDS $\times$ AMFs $\times$ PGPR on root volume (A), root dry weight (B), sepals' dry weight (C), number of sepals (D), 1000-seed weight (E), and seed yield of roselle (F)

\section{Number and dry weight of sepals}

The effects of WDS, AMFs, and PGPR treatments as well as the interaction WDS $\times$ AMFs $\times$ PGPR were significant on the number and dry weight of sepals of roselle. Drought stress decreased the number and dry weight of sepals while inoculation by AMFs increased. The highest sepal's dry weight $(3.66 \mathrm{~g})$ was related to the $F$. intraradicesinoculation under well-watered $\left(\mathrm{I}_{1}\right)$ and the lowest $(0.3 \mathrm{~g})$ to non-inoculation under severe stress $\left(\mathrm{I}_{4}\right)$. The results indicated that the AMFs inoculation under severe stress increased sepals dry weight compared to the non-inoculation (Figure 1C).

The number of sepals per plants that had been subjected to the severe water stress was significantly lower compared to the well-watered plants (Table 1). Plants cultivated under severe stress conditions that had

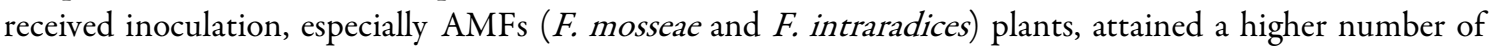
sepals per plants than non-inoculated plants. The highest number of sepals per plant was achieved in the $F$. mosseae inoculation with non-inoculation of PGPR under well-watered (13.0 number) and the application of Pseudomonas fluorescens with AMFs inoculation under well-watered treatment (12.6 number). The lowest this trait $\left(2.6\right.$ number) was found non-inoculation treatment (control) under severe water stress $\left(\mathrm{I}_{4}\right)$. In well- 
watered plants, number of sepals was increased by single AMFs and PGPR inoculation similarly to dual colonization (Figure 1D).

\section{0-seed weight}

1000-seed weight significantly influenced by WDS, AMFs, and PGPR as well as the interaction of WDS $\times$ AMFs $\times$ PGPR $(p \leq 0.01)$ (Table 1). In well-watered conditions $\left(I_{1}\right)$, the highest 1000 -seed weight $(38.6 \mathrm{~g})$ was observed in non-inoculation with the application of Pseudomonas fluorescens and the lowest $(9.43 \mathrm{~g})$ was achieved in control treatments (non-inoculation) under severe stress condition $\left(\mathrm{I}_{4}\right)$ (Figure 1E).

\section{Seed yield}

Seed yield significantly influenced by interaction of WDS, AMFs, and PGPR ( $p \leq 0.01)$. The severe stress $\left(\mathrm{I}_{4}\right)$ decreased seed yield by $72.25 \%$ compared to the well-watered $\left(\mathrm{I}_{1}\right)$. Also, the $F$. mosseae inoculation and the application of PGPR increased by $27.94 \%$ and $8.42 \%$ compared to the control treatment, respectively (Table 1). The highest seed yield was found under well-watered treatment by inoculation of $F$. mosseae without PGPR and the application of Pseudomonas fluorescens $(6.37$ and $6.51 \mathrm{~g} / \mathrm{plant})$. The lowest seed yield $(0.51$ $\mathrm{g} / \mathrm{plant}$ ) was achieved non-inoculation treatments under severe stress $\left(\mathrm{I}_{4}\right)$. Dual inoculated plants with AMFs and PGPR showed the decreasing seed yield under stress conditions, suggesting the antagonistic effects of AMFs and PGPR (Figure 1F).

\section{Stomatal conductivity}

As shown in Table 2, the stomatal conductivity significantly influenced by WDS, AMFs, and PGPR as well as the interaction of WDS $\times$ AMFs $\times$ PGPR $(p \leq 0.01)$. Results indicated that the WSD decreased the stomatal conductivity while the inoculation of AMFs and PGPR increased (Table 2). The highest stomatal conductivity was found under well-watered treatment by inoculation of F. mosseae without PGPR (17.83 $\mathrm{mol} / \mathrm{m} 2 . \mathrm{sec})$ and the application of Pseudomonas fluorescens without AMFs $(17.86 \mathrm{~mol} / \mathrm{m} 2 . \mathrm{sec})$. The lowest stomatal conductivity $(9.33 \mathrm{~mol} / \mathrm{m} 2 . \mathrm{sec})$ was achieved non-inoculation treatments under severe stress $\left(\mathrm{I}_{4}\right)$. Dual inoculated plants with AMFs and PGPR, under stress conditions $\left(\mathrm{I}_{3}\right.$ and $\left.\mathrm{I}_{4}\right)$, showed the increasing stomatal conductivity, suggesting the synergistic effects of AMFs and PGPR (Figure 2A).

Table 2. Correlation coefficients among yield components and physiological traits of roselle under WDS,

AMFs, and PGPR treatments

\begin{tabular}{|c|c|c|c|c|c|c|c|c|c|c|c|c|c|c|c|c|c|c|}
\hline & 1 & 2 & 3 & 4 & 5 & 6 & 7 & 8 & 9 & 10 & 11 & 12 & 13 & 14 & 15 & 16 & & 17 \\
\hline 1 & 1 & & & & & & & & & & & & & & & & & \\
\hline 2 & 0.44 & 1 & & & & & & & & & & & & & & & & \\
\hline 3 & 0.55 & 0.93 & 1 & & & & & & & & & & & & & & & \\
\hline 4 & 0.29 & 0.94 & 0.85 & 1 & & & & & & & & & & & & & & \\
\hline 5 & 0.32 & 0.93 & 0.85 & 0.92 & 1 & & & & & & & & & & & & & \\
\hline 6 & 0.25 & 0.8 & 0.74 & 0.74 & 0.84 & 1 & & & & & & & & & & & & \\
\hline 7 & 0.4 & 0.92 & 0.85 & 0.87 & 0.91 & 0.75 & 1 & & & & & & & & & & & \\
\hline 8 & 0.33 & 0.9 & 0.81 & 0.88 & 0.87 & 0.77 & 0.84 & 1 & & & & & & & & & & \\
\hline 9 & -0.35 & -0.89 & -0.86 & -0.86 & -0.88 & -0.76 & -0.89 & -0.82 & 1 & & & & & & & & & \\
\hline 10 & 0.4 & 0.97 & 0.92 & 0.94 & 0.94 & 0.81 & 0.92 & 0.9 & -0.89 & 1 & & & & & & & & \\
\hline 11 & 0.5 & 0.88 & 0.89 & 0.84 & 0.86 & 0.74 & 0.82 & 0.81 & -0.85 & 0.88 & 1 & & & & & & & \\
\hline 12 & 0.25 & 0.9 & 0.83 & 0.92 & 0.91 & 0.81 & 0.82 & 0.86 & -0.82 & 0.91 & 0.83 & 1 & & & & & & \\
\hline 13 & 0.44 & 0.92 & 0.91 & 0.9 & 0.91 & 0.79 & 0.85 & 0.86 & -0.88 & 0.93 & 0.98 & 0.92 & 1 & & & & & \\
\hline 14 & 0.47 & 0.94 & 0.88 & 0.92 & 0.89 & 0.73 & 0.89 & 0.92 & -0.86 & 0.94 & 0.81 & 0.85 & 0.86 & 1 & & & & \\
\hline 15 & 0.36 & -0.48 & -0.38 & -0.6 & -0.44 & -0.34 & -0.47 & -0.48 & 0.49 & -0.5 & -0.32 & -0.57 & -0.42 & -0.44 & 1 & & & \\
\hline 16 & -0.01 & -0.64 & -0.61 & -0.66 & -0.6 & -0.45 & -0.71 & -0.64 & 0.69 & -0.67 & -0.57 & -0.59 & -0.6 & -0.66 & 0.71 & 1 & & \\
\hline 17 & 0.45 & 0.66 & 0.7 & 0.58 & 0.63 & 0.58 & 0.73 & 0.69 & -0.61 & 0.7 & 0.61 & \begin{tabular}{l|l|}
0.66 \\
\end{tabular} & 0.65 & 0.69 & -0.24 & -0.49 & & 1 \\
\hline-1 & -0.9 & -0.8 & -0.7 & -0.6 & -0.5 & -0.4 & -0.3 & -0.2 & -0.1 & 0.1 & 0.2 & 0.3 & 0.5 & 0.6 & 0.7 & 0.8 & 0.9 & 1 \\
\hline & & & High & negative c & correlation & & & & on-correlatio & & & High posi & sitive corre & elation & & & & \\
\hline
\end{tabular}

1. Root colonization, 2. Root volume, 3. Root dry weight, 4. Sepals dry weight, 5. Number of sepals, 6. 1000-seed weight, 7. Seed yield, 8. Stomatal conductivity, 9. Osmotic potential, 10. RWC, 11. Chlorophyll a content, 12. Chlorophyll b content, 13. Total chlorophyll content. 14. Carotenoids content, 15. CAT activity, 16. POD activity, 17. Proline content. 

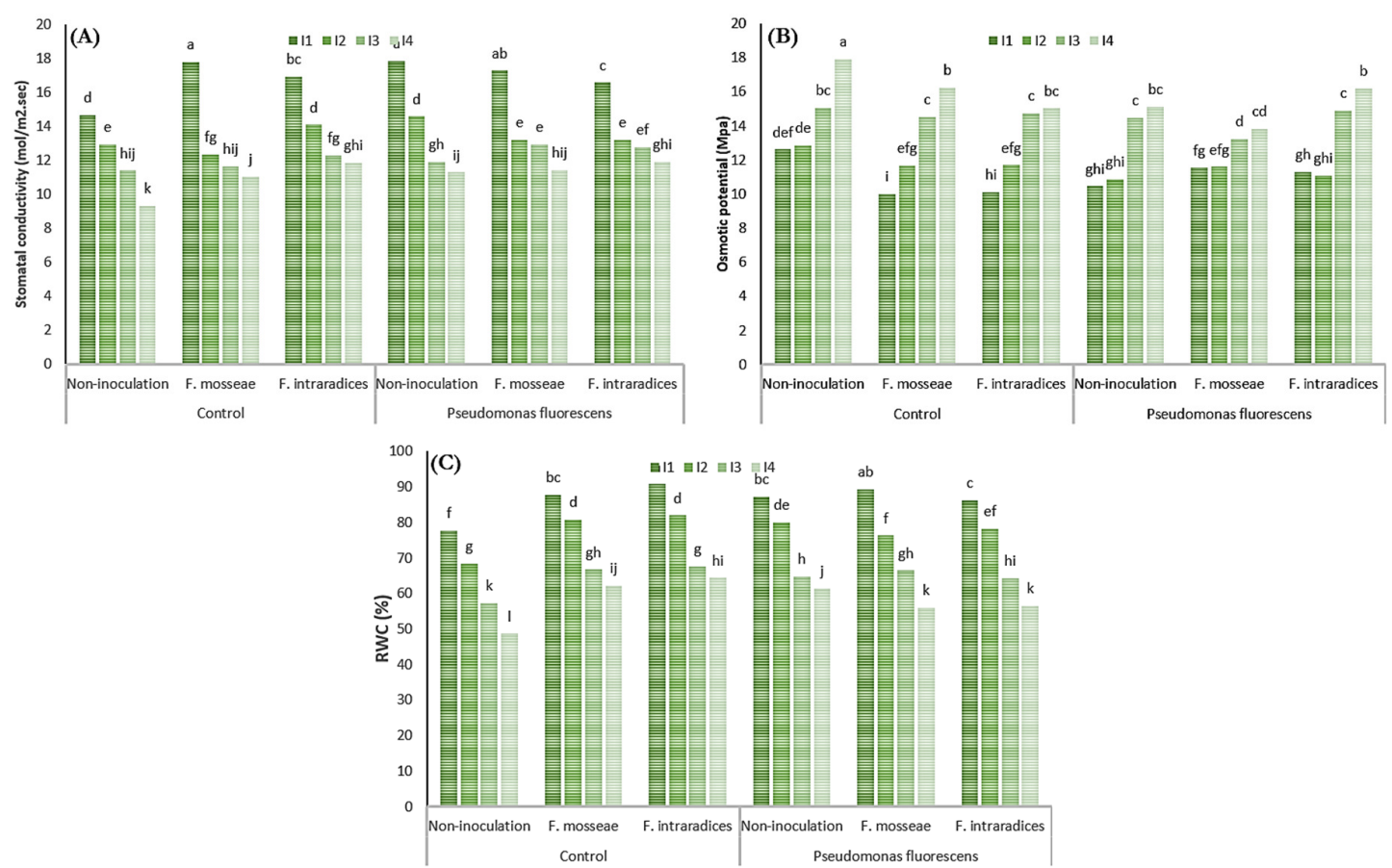

Figure 2. The interaction effects of WDS $\times$ AMFs $\times$ PGPR on stomatal conductivity (A), osmotic potential (B), and RWC of roselle(C)

\section{Osmotic potential}

The effects of WDS, AMFs, and PGPR treatments as well as the interaction WDS $\times$ AMFs $\times$ PGPR were significant on the osmotic potential (Table 1). Water deficit stress was caused by increasing the osmotic potential while the application of AMFs and PGPR decreased. The highest osmotic potential (17.93 MPa) was observed under severe stress $\left(\mathrm{I}_{4}\right)$ by non-inoculation with AMFs and PGPR and the lowest $(9.99 \mathrm{MPa})$ under well-watered treatment by F. mosseae without PGPR (Figure 2B).

\section{Relative water content}

As shown in Table 1, RWC significantly influenced by the interaction effects of WDS, AMFs, and $\operatorname{PGPR}(p \leq 0.01)$. The severe stress $\left(\mathrm{I}_{4}\right)$ decreased RWC by $32.68 \%$ compared to the well-watered $\left(\mathrm{I}_{1}\right)$. Also, the F. intraradices inoculation increased by $7.52 \%$ compared to the control treatment (Table 2 ). The highest RWC (90.6\%) was observed under well-watered by $F$. intraradices without PGPR and the lowest (48.6\%) under severe stress $\left(\mathrm{I}_{4}\right)$ treatment by non-inoculation with AMFs and PGPR (Figure 2C).

\section{Photosynthesis pigments}

Photosynthesis pigments such as $\mathrm{Chl} \mathrm{a}, \mathrm{b}$, and total $\mathrm{Chl}$ as well as carotenoids significantly influenced by interaction effects of WDS, AMFs, and PGPR $(p \leq 0.01)$. Contents of photosynthesis pigments decreased as a result of WDS while inoculated plants by AMFs and PGPR showed increased (Table 1). The highest Chl a, b, and total Chl were observed in inoculated plants by $F$. mosseae without PGPR under well-watered (6.23, 2.53 , and $8.76 \mathrm{mg} / \mathrm{g} \mathrm{FW}$, respectively) and the lowest these traits $(2.61,0.74$, and $3.35 \mathrm{mg} / \mathrm{g} \mathrm{FW})$ in noninoculation treatment under severe water stress (Figure 3A, B, and C). As shown Figure 3D, the application of AMFs and PGPR increased carotenoids content under water stress conditions $\left(\mathrm{I}_{3}\right.$ and $\left.\mathrm{I}_{4}\right)$ compared to the noninoculated plants. The highest and lowest carotenoids content $(2.21$ and $0.58 \mathrm{mg} / \mathrm{g} \mathrm{FW}$, respectively) was observed in the application of $F$. intraradices under well-watered $\left(\mathrm{I}_{1}\right)$ and the non-inoculation treatment under severe stress $\left(\mathrm{I}_{4}\right)$, respectively. 

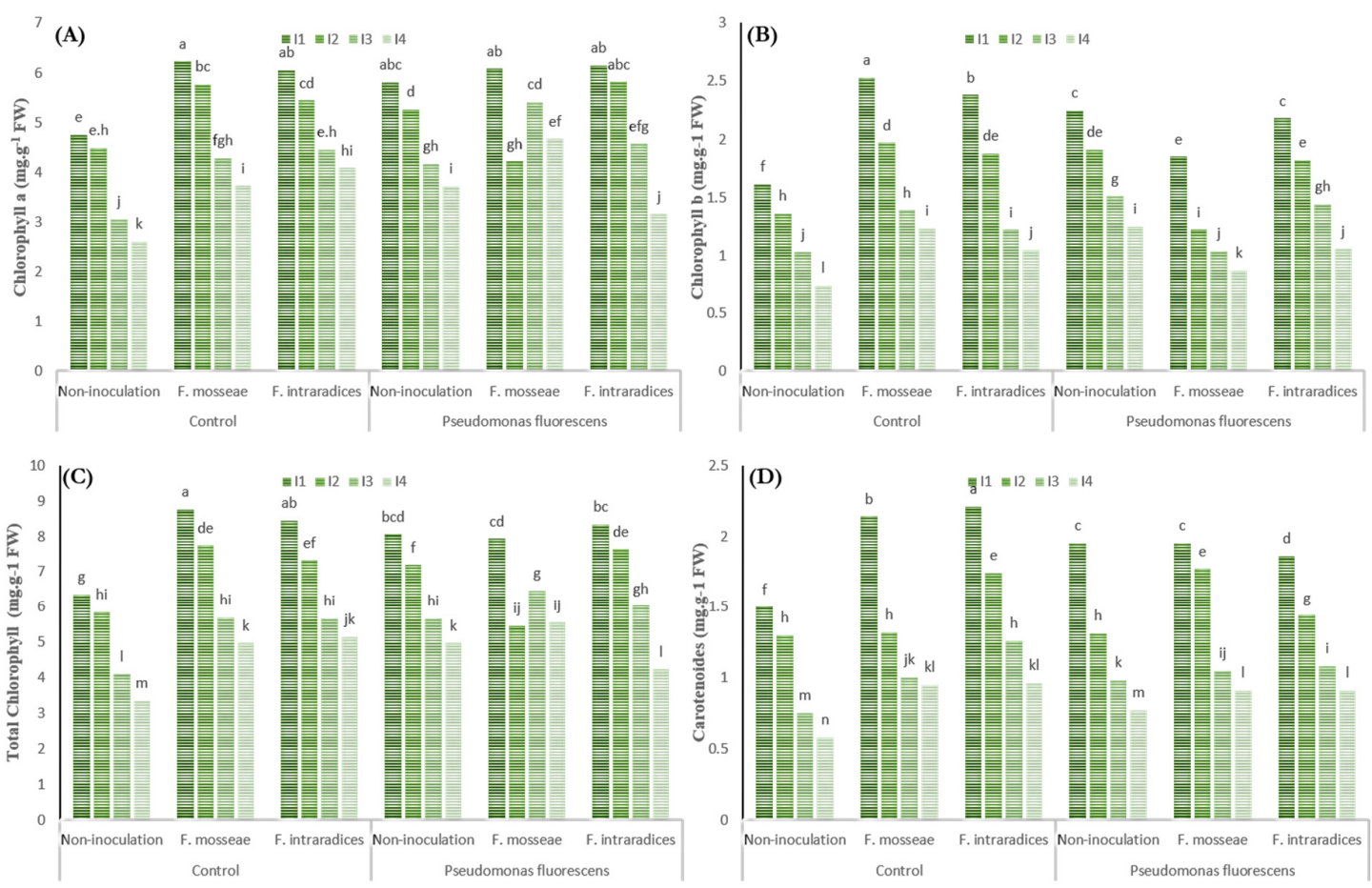

Figure 3. The interaction effects of WDS $\times$ AMFs $\times$ PGPR on chlorophyll a content $(A)$, chlorophyll $b$ content (B), total chlorophyll content $(\mathrm{C})$, and carotenoids content of roselle (D)

\section{Catalase and peroxidase activity}

The interaction effects of WDS, AMFs, and PGPR were significant in the activity of CAT and POD enzymes ( $p \leq 0.01)$. The results showed WSD and the application of AMFs and PGPR enhanced the activity of CAT and POD enzymes (Table 1). As shown in Figure 4, dual inoculated plants with $F$. mosseae and Pseudomonas fluorescens under severe stress (I4) showed the highest CAT activity (10.71 U/mg protein.min) and the lowest activity $(3.73 \mathrm{U} / \mathrm{mg}$ protein.min) related to non-inoculated plants under well-watered. In severe stress conditions (I4), POD activity was increased by single $F$. intraradices and Pseudomonas fluorescens inoculation similarly to dual colonization. POD activity ranged from $0.78 \mathrm{U} / \mathrm{mg}$ protein.min (control treatment) to $2.66 \mathrm{U} / \mathrm{mg}$ protein.min (Pseudomonas fluorescens inoculation without AMFs under severe stress) (Figure 4B).

\section{Proline content}

As shown in Table 1, proline content significantly influenced by WDS, AMFs, PGPR, as well as interaction effects of WDS $\times$ AMFs $\times$ PGPR. By increasing the intensity of water stress as well as the application of AMFs and PGPR, an increase in proline content was observed. Dual application of Pseudomonas fluorescens and $F$. mosseae under severe stress $\left(\mathrm{I}_{4}\right)$ showed the highest proline content $(12.55 \mu \mathrm{mol} / \mathrm{g} \mathrm{FW})$ and the lowest proline content related to the non-inoculation treatment under well-watered plants as well as $F$. intraradices inoculation without PGPR under non-stress conditions ( 4.45 and $4.44 \mu \mathrm{mol} / \mathrm{g} \mathrm{FW}$ ) (Figure 4C).

\section{Correlation coefficients}

The results of correlation coefficients are presented in Table 2. According to the results, there were significantly negative and positive correlations among yield components and physiological properties. For example, the morphological and seed yield components (such as root colonization, root volume, and dry weight, sepals' dry weight, number of sepals, 1000-seed weight, and seed yield, were significantly and positively correlated among themselves and with RWC, Chl a, b, and total Chl contents, as well as carotenoids content. 
However, the sepals' dry weight, seed yield, and pigment contents were negatively and significantly correlated with the enzymatic activities (CAT and POD) and with the osmotic potential.

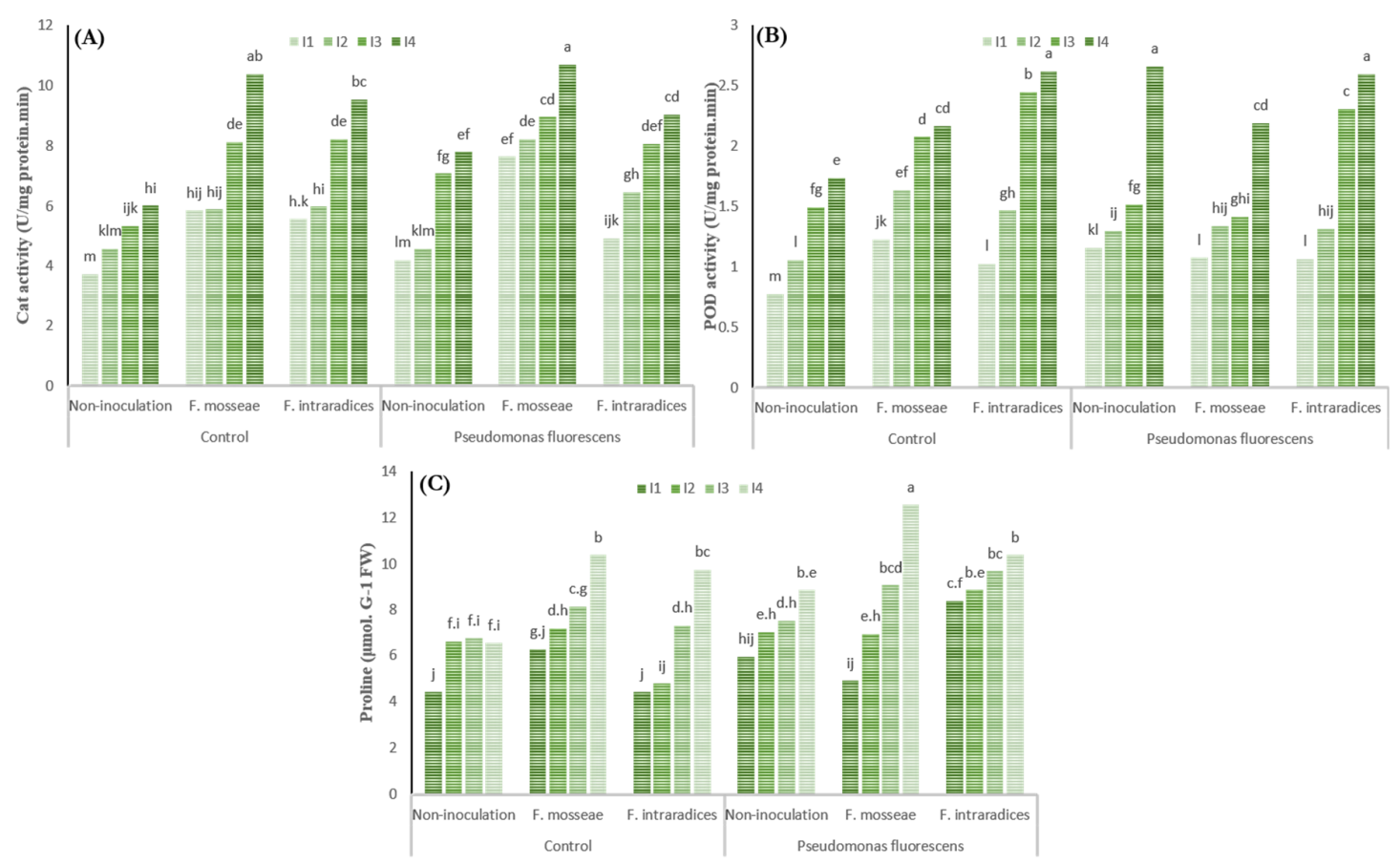

Figure 4. The interaction effects of WDS $\times$ AMFs $\times$ PGPR on CAT activity (A), POD activity (B), and proline content $(\mathrm{C})$

\section{Discussion}

The experiment aimed to determine the effects of AMFs and PGPR inoculation under WDS on morpho-physiological attributes of roselle grown in Iran. Results showed that the effects of WDS, AMFs, and PGPR, as well as the interaction of WDS $\times$ AMFs $\times$ PGPR, were significant on morphological traits and yield component (root volume and dry weight, sepals dry weight, number of sepals, 1000-seed weight, and seed yield) and physiological traits (stomatal conductance, osmotic potential, RWC, Chl a, Chl b, total Chl, carotenoids, the activity of CAT and POD enzymes, and proline content).

The effects of AMFs and PGPR on the physiological traits and yield components of roselle under WDS indicated that the microorganisms in the soil can alleviate the stress by regulating different plant morphological and physiological mechanisms. The stress significantly affected roselle physiological properties and decreased plant yield components. The AMFs improved plant physiology, growth, and yield under WDS by affecting the activity of antioxidant enzymes, (scavenging reactive oxygen species) and increasing plant pigments including $\mathrm{Chl}$ a, Chl b, and total Chl, and carotenoids. Accordingly, our results for the first time indicate the alleviating effects of AMFs on roselle physiology, growth, and yield components under WDS.

Plant water status can affect different physiological properties such as leaf turgor potential, plant growth, stomatal conductance, transpiration rate, photosynthesis, and respiration. Maintenance of plant water status is a fundamental phenomenon for the maintenance of normal growth of plants under stressful environments (Kusvuran, 2012). In this study, WDS adversely affected different plant-water relation parameters such as leaf water potential, osmotic potential, and RWC. The effects of each of the mycorrhizal and bacterial inoculants on the RWC of plants were obvious, whereas a maximized positive effect on water content was observed in single-inoculated plants by $F$. intraradices (Rahimzadeh and Pirzad, 2017). According to the previous research, 
increase plant tolerance to WDS by improving plant water relations, osmotic adjustment, increasing leaf gas exchange, photosynthesis, protection against oxidative damage caused by drought stress, and increasing nitrate reductase activity (Dutta et al., 2015). The accumulation of soluble matter led to osmosis regulation that is one of the mechanisms of adaptation under water shortage conditions.

Mycelium of mycorrhizal arbuscular fungus plays an important role in the effect of the fungus on the host plant water relations and absorbs water from very fine pores of the soil. Under WSD conditions, the water potential of AMFs inoculated plants were $21 \%$ more than non-inoculated plants. (Rouphael et al., 2015) reported that AMFs likely absorbed more water by changing root morphology, developing the host plant root, and increasing absorption surface through hyphae and improved the host plant water relations. The interaction between the plants and soil micro-organisms provided good conditions for water shortage stress (Verma et al., 2016). According to the experiment results, it seems that WDS can reduce RWC percentage, and using AMFs single or dual can play a role in reducing the adverse effects better than non-application. According to the experiment, with increasing proline content the leaf RWC was also reduced, and increasing proline indicated increasing drought stress severity and reducing water of plants which resulted in reduced leaf RWC.

In our experiment, WSD tended to diminish photosynthetic pigments such as $\mathrm{Chl}$ and carotenoids. Under well-watered conditions, however, the increased Chl content that we observed with single inoculation of AMFs by $F$. mosseae might have contributed to an increased rate of photosynthesis possibly related to a large number of chloroplasts in bundle sheaths in the leaves (Rahimzadeh and Pirzad, 2017). During stress, chloroplast decomposed and Thylakoid structures disappeared. On the other hand, drought stress disturbed enzyme systems reducing reactive oxygen activity and increasing lipid peroxidation and as a result damaged the cell membrane and pigment degradation (Ruíz-Sánchez et al., 2011). The reduction in Chl content under water shortage stress conditions observed in this study has been also reported by Misra and Srivastava (2000) in Japanese peppermint. Chlorophyll content in the mycorrhizal plants was increased due to improved phosphorus absorption. In pepper inoculated with $G$. intrstsdices, chlorophyll a and b significantly increased compared to non-mycorrhizal plants (Demir, 2005). AMFs can increase stomatal conductivity, photosynthesis, and finally chlorophyll of plants after water shortage stress (Selvaraj and Chellappan, 2006). The PGPR and AMFs have the potential to modulate and regulate plant physiological and biochemical responses to drought stress and therefore increase plant survival under severe and diverse environmental conditions (Marasco et al., 2012).

On the other hand, carotenoids act as pigments taking light in photosynthesis and could be classified as antioxidants removing free radicals in the plant used and thereby improving the stress oxidative incurred by the plant during adaptation (Kapoor et al., 2008). The increase in the content of photosynthetic pigments during the adaptation process by AMFs was previously studied by (Rahimzadeh and Pirzad, 2017). Misra and Srivastava (2000) in a study on Japanese peppermint (Mentha arvensis) observed that water shortage stress significantly reduced Chl content. PGPR and AMFs have the potential to modulate and regulate plant physiological and biochemical responses to drought stress, thereby enhancing plant survival under bad and diverse environmental conditions (Marasco et al., 2012).

In our study, all enzyme activities (CAT and POD enzymes) enhanced with increasing water stress intensity. Also, increased enzyme activities in inoculated plants by AMFs and PGPR indicated that the microorganisms alleviated the oxidative damage from water shortage. Similar to our results, (Rahimzadeh and Pirzad, 2017) found that inoculation with Pseudomonas augmented antioxidants under severe drought stress, suggesting that they can alleviate the drought-induced oxidative damage. Additionally, symbiosis with AMFs helps plants to cope with drought stress, probably by maintaining photosynthetic processes intact or little altered as a result of a rise in antioxidant activities (Rouphael et al., 2015). The plants have different mechanisms to reduce the adverse effects of reactive oxygen species, including enzymatic and non-enzymatic antioxidant defence system. Antioxidant enzymes include CAT, superoxide dismutase, POD, polyphenol oxidase, and ascorbate peroxidase, which are involved in removing oxygen free radicals in the cell, as well as the most important constituents and the first defence against damage (Pan et al., 2005). Under severe WDS 
conditions, the increase of leaf CAT activity in Pseudomonas fluorescens-treated and mycorrhizal plants that we observed suggests that inoculated plants might have the potential to activate this enzyme to counteract oxidative, water deficit-induced damage (Ghorbanpour et al., 2013). Thus, the inoculants were able to regulate oxidative reactions and antioxidant defence (Ortiz et al., 2015).

Increasing drought stress increased CAT enzyme activity that increased plant tolerance to drought stress. Superoxide dismutase enzyme that is increased under stress conditions is the first enzyme that is activated in the antioxidant cycle (Chakraborty and Pradhan, 2012). It acts as the first defence antioxidant system against reactive oxygen molecular forms and converts free radicals into $\mathrm{H}_{2} \mathrm{O}_{2}$ created by water and oxygen molecules by CAT and POD (Gratão et al., 2005). It has been shown that PGPR by producing antioxidant factors or modulating photosynthesis reduces the damage of reactive oxygen species and can protect the plant against the presence of reactive oxygen species and prevent damage to the plant (Young et al., 2013). Peroxidase as a catalyst converts glutathione to glutathione disulfide and is involved in the conversion of hydrogen peroxide to water. Glutathione affects the activity of di-ascorbate reductase enzyme that converts di-hydro-ascorbate to ascorbate (Hossain and Fujita, 2012). Under stress, all major plant processes such as energy production, lipid metabolism, and antioxidant enzyme activity are affected (Weisany et al., 2012). Erdogan et al. (2016) concluded that plants inoculated with PGPR had higher antioxidant enzyme activity such as CAT, POD, and APX).

The reported results increase in leaf proline content in consequence of increasing WSD suggest that the proline accumulation probably is a common response of roselle under water deficit as an osmotic adjustment. The lower content of proline may be attributed to either greater drought resistance or less injury of colonized plants under drought stress conditions, and proline content was lower in single-inoculant treatments than in dual-inoculation treatments (Rahimzadeh and Pirzad, 2017). Although damage to cell membranes by water stress probably limits osmotic adjustment, high leaf water content under drought stress may prevent the accumulation of osmolytes such as proline content. Pirzad et al. (2011) reported an increase in proline content due to water shortage stress in Matricaria chamomilla L. It has also been reported that the application of PGPR by removing oxygen free radicals reduces the damage to fatty acids and proteins, and thus reduces the destructive effect of stress, thereby reducing proline synthesis and accumulation as a plant reaction to stress (Agami et al., 2016). AMFs were more effective in increasing proline content at high levels of severe stress and had a higher leaf proline accumulation compared to non-inoculated plants. Usually, plants inoculated with AMFs using water and better nutrition to the plants without AMFs are capable to tolerate drought conditions temporarily and are less damaged, and therefore levels of proline in plants without mycorrhiza increased less. Based on the experiment, increased proline content showed the highest intensity of water stress and reduced RWC of the leaf.

\section{Conclusions}

According to previous studies on AMFs and plants symbiosis and the study results, we concluded that mycorrhizal plants for the advantages of symbiosis with AMFs through increasing the uptake of minimum water available in the soil by fungal hyphae as well as reducing the amount of water loss by reducing leaf area, Chl content and finally photosynthesis rate during the stress period have shown greater resistance to nonmycorrhizal plants, thereby improving the recovery of this plant in warm and arid areas. The study results showed that WDS significantly reduced all yield components. The application of PGPR or AMFs (especially) is important for emphasizing reducing the negative environmental impacts of chemical fertilizers, which can be a good alternative for them. According to the results obtained from this experiment, it can be stated that although with reducing water use and consequently WSD occurrence, the plant dry matter yield is reduced, using bio-fertilizers especially at higher levels of drought stress to some extent we can reduce the adverse effects on the plant productivity which can be attributed to the positive effect of bio-fertilizers on improving the plant nutrient conditions under WSD. 


\section{Authors' Contributions}

$\mathrm{MB}, \mathrm{AEKG}$ and MTG supervised and designed the experiment. SS performed the experiment, analysed the parameters, SS and MTG analysed the data. SS wrote the paper. MB and AEKG improved the language and English writing of the entire manuscript. All authors read and approved the final manuscript.

\section{Acknowledgements}

This research received no specific grant from any funding agency in the public, commercial, or not-forprofit sectors.

\section{Conflict of Interests}

The authors declare that there are no conflicts of interest related to this article.

\section{References}

Agami R, Medani R, Abd El-Mola I, Taha R (2016). Exogenous application with plant growth-promoting rhizobacteria (PGPR) or proline induces stress tolerance in basil plants (Ocimum basilicum L.) exposed to water stress. International Journal of Environmental and Agriculture Research 2:78-82.

Aghighi Shahverdi M, Omidi H, Tabatabaei SJ (2019). Stevia (Stevia rebaudiana Bertoni) responses to $\mathrm{NaCl}$ stress: Growth, photosynthetic pigments, diterpene glycosides and ion content in root and shoot. Journal of the Saudi Society of Agricultural Sciences 18:355-360. https://doi.org/10.1016/j.jssas.2017.12.001

Ahanger MA, Tomar NS, Tittal M, Argal S, Agarwal RM (2017). Plant growth under water/salt stress: ROS production; antioxidants and significance of added potassium under such conditions. Physiology and Molecular Biology of Plants 23:731-744. https://doi.org/10.1007/s12298-017-0462-7

Ahmad N, Sharma S, Alam MK, Singh V, Shamsi S, Mehta B, Fatma A (2010). Rapid synthesis of silver nanoparticles using the dried medicinal plant of basil. Colloids, and Surfaces B: Biointerfaces 81:81-86. https://doi.org/10.1016/j.colsurfb.2010.06.029

Ahmadi SAK, Ebadi A, Daneshian J, Jahanbakhsh S, Siadat SA, Tavakoli H (2015). Effects of irrigation deficit and application of some growth regulators on defense mechanisms of canola. Notulae Botanicae Horti Agrobotanici Cluj-Napoca 43:124-130. https://doi.org/10.15835/nbha4319668

Al-Arjani AF, Hashem A, Abd Allah EF (2020). Arbuscular mycorrhizal fungi modulate dynamics tolerance expression to mitigate drought stress in Ephedra foliata Boiss. Saudi Journal of Biological Sciences 27:380-394.

Amiri R, Nikbakht A, Etemadi N, Sabzalian MR (2016). Nutritional status, essential oil changes, and water-use efficiency of rose geranium in response to arbuscular mycorrhizal fungi and water deficiency stress. Symbiosis 73:15-25. https://doi.org/10.1007/s13199-016-0466-Z

Arnon A (1967). Method of extraction of chlorophyll in the plants. Agronomy Journal 23:112-121.

Awasthi R, Tewari R, Nayyar H (2011). Synergy between plants and P-solubilizing microbes in soils: effects on growth and physiology of crops. International Research Journal of Microbiology 2:484-503.

Carrasco-Ríos L, Pinto M (2014). Effect of salt stress on antioxidant enzymes and lipid peroxidation in leaves in two contrasting corn, Jubilee. Chilean Journal of Agricultural Research 74:89-95. http://dx.doi.org/10.4067/S0718-58392014000100014

Chakraborty U, Pradhan B (2012). Oxidative stress in five wheat varieties (Triticum aestivum L.) exposed to water stress and study of their antioxidant enzyme defense system, water stress responsive metabolites and $\mathrm{H}_{2} \mathrm{O}_{2}$ accumulation. Brazilian Journal of Plant Physiology 24:117-130.

Da-Costa-Rocha I, Bonnlaender B, Sievers H, Pischel I, Heinrich M (2014). Hibiscus sabdariffa L. - a phytochemical and pharmacological review. Food Chemistry 165:424-443. https://doi.org/10.1590/S1677-04202012000200005 
Demir S (2005). Influence of arbuscular mycorrhiza on some physiological growth parameters of pepper. Turkish Journal of Biology 28:85-90.

Dutta S, Patel V, Viswanathan C, Singh S, Singh A (2015). Physiological and biochemical adaptation of arbuscular mycorhizal fungi (AMF) inoculated Citrus jambhiri (Jatti khatti) seedlings under water deficit stress conditions. Progressive Horticulture 47:229-236. https://doi.org/10.5958/2249-5258.2015.00041.X

Erdogan U, Cakmakci R, Varmazyarı A, Turan M, Erdogan Y, Kıtır N (2016). Role of inoculation with multi-trait rhizobacteria on strawberries under water deficit stress. Zemdirbyste-Agriculture 103:67-76. https://doi.org/10.13080/z-a.2016.103.009

Esmaielpour B, Jalilvand P, Hadian J (2013). Effects of drought stress and arbuscular mycorrhizal fungi on some morphophysiological traits and yield of savoury (Satureja hortensis L.). Agroecology 5(2):169-177.

Fallahi HR, Ghorbany M, Aghhavani-Shajari M, Samadzadeh A, Asadian AH (2017). Qualitative response of roselle to planting methods, humic acid application, mycorrhizal inoculation and irrigation management. Journal of Crop Improvement 1:17-24. https://doi.org/10.1080/15427528.2016.1269378

Ghorbanpour M, Hatami M, Khavazi K (2013). Role of plant growth promoting rhizobacteria on antioxidant enzyme activities and tropane alkaloid production of Hyoscyamus niger under water deficit stress. Turkish Journal of Biology 37:350-360. https://doi.org/10.3906/biy-1209-12

Giovannetti M, Mosse B (1980). An evaluation of techniques for measuring vesicular arbuscular mycorrhizal infection in roots. New Phytologist 489-500. https://doi.org/10.1111/j.1469-8137.1980.tb04556.x

Gleason SM (2015). Evolutionary outcomes should inform strategies to increase drought tolerance. Nature Plants 1:15114. https://doi.org/10.1038/nplants.2015.114

Gouda S, Kerry RG, Das G, Paramithiotis S, Shin HS, Patra JK (2018). Revitalization of plant growth-promoting rhizobacteria for sustainable development in agriculture, Microbiological Research 206:131-140. https://doi.org/10.1016/j.micres.2017.08.016

Gratão PL, Polle A, Lea PJ, Azevedo RA (2005). Making the life of heavy metal-stressed plants a little easier. Functional Plant Biology 32:481-494. https://doi.org/10.1071/FP05016

Hossain M, Fujita M (2012). Regulatory role of components of ascorbate-glutathione (AsA-GSH) pathway in plant tolerance to oxidative stress, oxidative stress in plants: causes, consequences and tolerance. IK International Publishing House Pvt. Ltd., India pp 81-147.

Irigoyen J, Einerich D, Sánchez-Díaz M (1992). Water stress-induced changes in concentrations of proline and total soluble sugars in nodulated alfalfa (Medicago sativd) plants. Physiologia Plantarum 84:55-60. https://doi.org/10.1111/j.1399-3054.1992.tb08764.x

Kapoor R, Sharma D, Bhatnagar A (2008). Arbuscular mycorrhizae in micropropagation systems and their potential applications. Scientia Horticulturae 116:227-239. https://doi.org/10.1016/j.scienta.2008.02.002

Kar M, Mishra D (1976). Catalase, peroxidase, and polyphenoloxidase activities during rice leaf senescence. Plant Physiology 57:315-319. https://doi.org/10.1104/pp.57.2.315

Kumar V, Kumar P, Khan A (2020). Optimization of PGPR and silicon fertilization using response surface methodology for enhanced growth, yield and biochemical parameters of French bean (Phaseolus vulgaris L.) under saline stress. Biocatalysis and Agricultural Biotechnology 23:22-27. https://doi.org/10.1016/j.bcab.2019.101463

Kusvuran S (2012). Effects of drought and salt stresses on growth, stomatal conductance, leaf water and osmotic potentials of melon genotypes (Cucumis melo L.). African Journal of Agricultural Research 7:775-781. https://doi.org/10.5897/AJAR11.1783

Marasco R, Rolli E, Ettoumi B, Vigani G, Mapelli F, Borin S, ... Cherif A (2012). A drought resistance-promoting microbiome is selected by root system under desert farming. PLoS One 7:e48479. https://doi.org/10.1371/journal.pone.0048479

Misra A, Srivastava N (2000). Influence of water stress on Japanese mint. Journal of Herbs, Spices \& Medicinal Plants 7:51-58. https://doi.org/10.1300/J044v07n01_07

Narula N, Kumar V, Behl RK, Deubel A, Gransee A, Merbach W (2000). Effect of P-solubilizing Azotobacter chroococcum on N, P, K uptake in P-responsive wheat genotypes grown under greenhouse conditions. Journal of Plant Nutrition and Soil Science 163:393-398.

https://doi.org/10.1002/1522-2624(200008)163:4<393::AID-JPLN393>3.0.CO;2-W 
Ortiz N, Armada E, Duque E, Roldán A, Azcón R (2015). Contribution of arbuscular mycorrhizal fungi and/or bacteria to enhancing plant drought tolerance under natural soil conditions: effectiveness of autochthonous or allochthonous strains. Journal of Plant Physiology 174:87-96. https://doi.org/10.1016/j.jplph.2014.08.019

Pan J, Wang Q, Snell WJ (2005). Cilium-generated signaling and cilia-related disorders. Laboratory Investigation 85:452463. https://doi.org/10.1038/labinvest.3700253

Phillips JM, Hayman D (1970). Improved procedures for clearing roots and staining parasitic and vesicular-arbuscular mycorrhizal fungi for rapid assessment of infection. Transactions of the British Mycological Society 55:158-161. https://doi.org/10.1016/S0007-1536(70)80110-3

Pirzad A, Shakiba MR, Zehtab-Salmasi S, Mohammadi SA, Darvishzadeh R, Samadi A (2011). Effect of water stress on leaf relative water content, chlorophyll, proline and soluble carbohydrates in Matricaria chamomilla L. Journal of Medicinal Plants Research 5:2483-2488.

Qiao Y, Ren J, Yin L, Liu Y, Deng X, Liu P, Wang S (2020). Exogenous melatonin alleviates PEG-induced short-term water deficiency in maize by increasing hydraulic conductance. BMC Plant Biology 20:218. https://doi.org/10.1186/s12870-020-02432-1

Rahimzadeh S, Pirzad A (2017). Arbuscular mycorrhizal fungi and Pseudomonas in reduce drought stress damage in flax (Linum usitatissimum L.): a field study. Mycorrhiza 27:537-552.

Riaz G, Chopra R (2018). A review on phytochemistry and therapeutic uses of Hibiscus sabdariffa L. Biomed Pharmacother 102:575-586.

Rouphael Y, Franken P, Schneider C, Schwarz D, Giovannetti M, Agnolucci M, .. Colla G (2015). Arbuscular mycorrhizal fungi act as biostimulants in horticultural crops. Scientia Horticulturae 196:91-108. https://doi.org/10.1016/j.scienta.2015.09.002

Ruíz-Sánchez M, Armada E, Muñoz Y, de Salamone IEG, Aroca R, Ruíz-Lozano JM, Azcón R (2011). Azospirillum and arbuscular mycorrhizal colonization enhance rice growth and physiological traits under well-watered and drought conditions. Journal of Plant Physiology 168:1031-1037. https://doi.org/10.1016/j.jplph.2010.12.019

Sbrana C, Avio L, Giovannetti M (2014). Beneficial mycorrhizal symbionts affecting the production of health-promoting phytochemicals. Electrophoresis 35:1535-1546. https://doi.org/10.1002/elps.201300568.

Selvaraj T, Chellappan P (2006). Arbuscular mycorrhizae: a diverse personality. Journal of Central European Agriculture 7:349-358.

Sharma A, Shahzad B, Kumar V, Kohli SK, Sidhu GPS, Bali AS, ... Zheng B (2019). Phytohormones regulate accumulation of osmolytes under abiotic stress. Biomolecules 9(7):285. https://doi.org/10.3390/biom9070285

Shoresh M, Harman GE, Mastouri F (2010). Induced systemic resistance and plant responses to fungal biocontrol agents, Annual Review of Phytopathology 48:21-43. https://doi.org/10.1146/annurev-phyto-073009-114450

Soengas P, Rodriguez VM, Velasco P, Cartea ME (2018). Effect of temperature stress on antioxidant defenses in Brassica oleracea. ACS Omega 3:5237-5243. https://doi.org/10.1021/acsomega.8b00242

Verma P, Saxena R, Tomar RS (2016). Rhizobacteria: A promising tool for drought tolerance in crop plants. International Journal of Pahrma and Bio Science (Int-BIONANO-2016) 116-125.

Vurukonda SS, Vardharajula S, Shrivastava M, Sk ZA (2016). Enhancement of drought stress tolerance in crops by plant growth-promoting $\quad$ rhizobacteria. Microbiological 184:13-24. https://doi.org/10.1016/j.micres.2015.12.003

Wang CJ, Yang W, Wang C, Gu C, Niu DD, Liu HX, ... Guo JH (2012). Induction of drought tolerance in cucumber plants by a consortium of three plant growth-promoting rhizobacterium strains. PLoS One 7:e52565. https://doi.org/10.1371/journal.pone.0052565

Weisany W, Sohrabi Y, Heidari G, Siosemardeh A, Ghassemi-Golezani K (2012). Changes in antioxidant enzymes activity and plant performance by salinity stress and zinc application in soybean (Glycine max L.). Plant Omics 5:60-68.

Young LS, Hameed A, Peng SY, Shan YH, Wu SP (2013). Endophytic establishment of the soil isolate Burkholderia sp. CC-Al74 enhances growth and P-utilization rate in maize (Zea mays L.). Applied Soil Ecology 66:40-47. https://doi.org/10.1016/j.apsoil.2013.02.001 
OPEN ACCESS

(c) (2)

The journal offers free, immediate, and unrestricted access to peer-reviewed research and scholarly work. Users are allowed to read, download, copy, distribute, print, search, or link to the full texts of the articles, or use them for any other lawful purpose, without asking prior permission from the publisher or the author.

License - Articles published in Notulae Botanicae Horti Agrobotanici Cluj-Napoca are Open-Access, distributed under the terms and conditions of the Creative Commons Attribution (CC BY 4.0) License. (C) Articles by the authors; UASVM, Cluj-Napoca, Romania. The journal allows the author(s) to hold the copyright/to retain publishing rights without restriction. 